Article

\title{
Sustainability of Green Tourism among International Tourists and Its Influence on the Achievement of Green Environment: Evidence from North Cyprus
}

\author{
Samah Ibnou-Laaroussi ${ }^{1}$, Husam Rjoub ${ }^{2, * \mathbb{C}}$ and Wing-Keung Wong ${ }^{3}$ \\ 1 Department of Business Administration, Faculty of Economics and Administrative Sciences, \\ Cyprus International University, Mersin 10, Haspolat 99040, Turkey; 21707524@student.ciu.edu.tr \\ 2 Department of Accounting and Finance, Faculty of Economics and Administrative Sciences, \\ Cyprus International University, Mersin 10, Haspolat 99040, Turkey \\ 3 Department of Finance, Fintech Center, and Big Data Research Center Asia University, \\ Taichung 41354, Taiwan; wong@asia.edu.tw \\ * Correspondence: hrjoub@ciu.edu.tr
}

Received: 11 June 2020; Accepted: 2 July 2020; Published: 15 July 2020

\begin{abstract}
Sustainability of green tourism is gaining more attention from different stakeholders due to its environmental benefits. However, empirical studies on the behavioral aspect of the tourists towards sustainability of green tourism and its influence on the achievement of the green environment have not been exhaustively researched, most especially in a small island state like North Cyprus. In this paper, we investigate the behavioral aspects of international tourists towards the sustainability of green tourism employing an extended framework of the theory of planned behavior (TPB). A sample of 395 questionnaires was administered to the tourists that lodged at the 20 randomly selected five-star hotels in North Cyprus, while the study model was examined through structural equation modelling (SEM). Our study findings indicated that tourists' perceptions of the sustainability of green tourism and their environmental concerns had a significantly positive impact on their attitudes. In addition, our results revealed that subjective norms had a significantly negative impact on intentions of the tourists to participate in sustainability of green tourism, while attitude was found to have a significantly positive impact on the tourists' intentions to participate in the sustainability of green tourism. Moreover, we found that both environmental concerns and the intention of the tourists to participate in the sustainability of green tourism had a significantly positive impact on environmentally responsible tourism behavior. Lastly, our study contributes to enhancing the understanding of the perception of tourists on the green environment as it affects their behavior and subsequent influence on their intention to participate in the sustainability of green tourism with the attendant impact on the achievement of environmental degradation reduction.
\end{abstract}

Keywords: sustainability; green tourism; environmental degradation; theory of planned behavior; SEM; North Cyprus

\section{Introduction}

In the past decades, trepidation over environmental challenges has increased, and global warming, climate change, greenhouse gases effects (GHGs), and pollution have become ubiquitous and mainly caused by human activities generating carbon emissions [1], excessive consumption of energy and water, and abusive use of natural resources [2-4]. Henceforth, environmental problems are inescapable, which incites the prompt intervention of contemporary society to promote sustainable development, to protect biodiversity, and to face the climate change challenge $[5,6]$. Thus, it is necessary to work on the three dimensions of sustainable development (society, environment, and economy) to 
achieve sustainability and enhance green growth among different industries. Yet, green growth among people is founded through their urge of commitment to green activities and environmentally responsible behaviors.

The tourism industry is a quickly growing sector and may end up as the major source of global greenhouse gas emission (GHG). Its growth can be visualized as a matter of a double-edged sword in that tourism involves premium energy absorption, and massive contributions to waste generation and $\mathrm{CO}_{2}$ emissions through its various functions and operations [7] on the one hand, and an essential source of economic growth and an enriching cultural base for communities [8-11] on the other hand. For many years, research on tourism sustainability has increased greatly due to the major contribution of tourism to economic development, especially in cases of small islands states that show consistent recent growth. Furthermore, small island destinations provide environmental landscapes and promote environmental awareness through their variety of hotels and adapted green practices in the hospitality sector, which enhance their green destination image. Therefore, the green tourism concept has been promoted in several countries to reduce carbon emissions resulting from tourist and hotel management operator practices. Thus, the environmental development was crucial to minimize environmental degradation of tourists due to the attraction to nature-based destinations. Therefore, structured tourism activities are necessary, and the appeal for the assessment of tourism sustainability to progress is of a high priority [12]. Since the declaration of the United Nations in 2017 of the International Year of Sustainable Tourism, this sector has increasingly obtained devotion among several industries. United Nations World Tourism Organization (UNWTO) [13] defines sustainable tourism as tourism that yields current and future economic, environmental, and social impacts on the needs of the industry, visitors, the host communities, and the environment. Thereby, "green" or "sustainable" tourism advocates for minimal detrimental impacts on the local environment, and the enhancement and promotion of cultural benefits in the region for its local inhabitants [14]. It also seeks to answer to the urgent call of the global environmental challenge of climate change, not only to minimize the impact of climate change but also to reduce the effects of several environmental problems such as pollution, greenhouse gas emissions, and $\mathrm{CO}_{2}$ emissions, which are pivotal for discussion in this context, recognizing that green tourism consequently intends to reduce the unfavorable impacts on the local environment and foreseeing it applicability to the global scale. Mainly, the promoted green tourism industry highlights sustainability programs and induces motivational incentives offers that contribute to exhibiting the destination green image that has an emotional impact on tourists' pro-environmental behavior [15]. Hence, it identifies people's pragmatic outlook of tourism with a large commitment to the nature-based destination and a strategic affinity to contribute to environmental greening and enhancing people's lives when most tourism and hospitality sectors identify their operations and management to be subsequently following environmentally friendly measures.

It is necessary to promote environmental conservation [16]. Discussions on tourism sustainability have had a substantial expansion over recent decades for many reasons, where sustainability explicates the interconnection of three pillars "environment, economy, and society" [17]. In recent years, the panoply of studies conducted on sustainable tourism have shown theoretical progress but limited practices [18]. Sustainability in tourism conceptualizes the environmental aspects of tourism through environmental protection from many environmental problems such as minimizing air, water, and soil pollution and also reducing the waste produced by travelers and practitioners. Meanwhile, it focuses on maintaining the environmentally friendly characteristic of the landscape, habitats, wild plants, and animals. The second point is about social development, which refers to the quality of life of local inhabitant, and herein, it identifies the maintenance of the quality, history, culture, and diversity of the places of the destination. The economic pillar contributes to local economic prosperity by generating competitive advantages and increases in revenue through animating more viable and competitive destinations locally and globally. Beyond this context, Singh et al. [19] argued that the implementation of adequate waste management practices like recycling and composting could reduce greenhouse gas emission. Previous studies on green hotels found a significant positive link between 
green trust and travelers' intentions to participate in green practices [20], which requires effective sustainability communication [21]. Prior studies have shown positive pro-environmental behaviors with lodging in green hotels [22-25]. Tiago et al. [26] pinpointed the green tourism offers of services and their concerns of green certification of lodgings and the influence of travelers' green preferences on their buying behaviors and decisions. In that context, green management would advance tourism sustainability performance [27] and promote a sustainable lifestyle with advanced implications for tourists of better environmental responsible practices [28,29]. Therefore, marketed messages and unbiased information about environmentally responsible practices are dependent on the efforts of managers to keep trustworthy tourists updated. In addition, hotels' sustainable measures validated by hotel management decision-making are financially evaluated through the economic factors to maintain hotels in operation regarding demand and minimal costs required. From the perspective of guests, sustainability measures altruistically provide an advantageous perception of hotels championing such practices.

In this study, we employ a model that advocates tourists' intentions to perform pro-environmental behaviors that depends on three psychological variables: (1) favorable or unfavorable reactions (attitude); (2) social influence inciting behavior (subjective norms), and (3) the perceived ease of conducting the behavior (perceived behavioral control). Therefore, the theory of planned behavior (TPB) aims to be an accurate predictor of individual behavioral intention. According to Li et al. [30], consumers are willing to buy energy-efficient appliances to reduce energy consumption and carbon emission of daily use. Numerous studies examined consumers' environmental and attitudinal behaviors and environmental behaviors towards the extent of green product consumption and pro-environmental purchasing [31-35] and green food consumption [36]. While several researchers contend that the TPB interpreted a minor consideration for the interactions between the three predictors and demographics factors [37], only a few studies discussed the impact of international tourists behavioral intentions in the context of sustainability of green tourism and environmental degradation and the attempt to determine several aspects influencing international tourists' behavioral intentions to immediately consider their environmentally responsible tourism behaviors. In spite of the panoply of studies focused on the sustainability of green tourism, only a few of them paid attention to the sustainability of green tourism perception of international tourists in a particular destination (e.g., small islands) focusing on their behavioral intentions in both reducing environmental degradation and promoting environmental protection, and thus achieving green growth. Not only are islands small in area, but they preserve the indigenous ecological environment and maintain special fauna and flora. Henceforth, the impact on sustainable development of island tourism is serious and involves an urgent appeal to tourists to increase efforts around environmental protection [38].

To respond to what is lacking in the hospitality marketing literature, we conceived two variables using an extended TPB: environmental concern (EC) and green tourism perception (GTP). Our analysis provided evidence of people located on the island of the Turkish Republic of North Cyprus (TRNC). In our study, we aimed to analyze consumers' behavioral aspects of green growth in the tourism industry. Thus, this study is relevant to effectively be used in green marketing strategies for environmental benefits, society, and sustainable companies. These strategies are used by practitioners to target guests whose identifications are authentically and identically going along with environmental protection. As discussed in the above, our study contribution is not only valid in the literature but also demonstrates managerial implications and promotes eventual results to practitioners.

\section{Literature Review}

\subsection{Theory of Planned Behavior}

International tourists look for international tourism destinations where attractive natural and cultural resources exist followed by the great diversity of several aspects and valuable heritage. Thus, small islands offer the experience wanted from international tourists. Consequently, the environmentally 
responsible tourism behavior appeared to investigate international tourists' perceptions of the sustainability of green tourism and enhance their experience without destroying the environmental sensitivity of small islands. Therefore, we used the theory of planned behavior for further prediction of international tourists' environmental responsible behaviors. The theory of planned behavior is an extendable psychology theorem proposed by [39]. It is a research tool that predicts individuals' behavioral intentions and actual behaviors [40]. This theory is one of the main researched theories to explain individual behaviors [41]. It includes rational predictors and assigns to self-interest motives and also to pro-social motives [42]. Numerous scholars pointed out the need to add pro-social variables to the TPB model, which has been successfully and broadly pragmatic in several studies to explicate various aspects of environmental behaviors, such as sustainable healthcare [43], green hotels [44,45], tourism studies [46], house rentals [47], rural development [48], the fashion industry [49], picking up litter in protected areas [50], urban bike-sharing for holiday cycling [51], sustainable agriculture [52-54], sustainable education [55], sustainable heritage tourism [56], sustainable consumption [57], energy-saving [58], water conservation [59,60], e-waste recycling [61], and sustainable transportation [62]. Henceforth, the extended TPB model was revealed to have stronger predictive power than the original TPB model [63]. Findings in a study in India suggested that the extended TPB model was more appropriate in predicting the adoption intention of electric vehicle customers [64]. This theory claims that behaviors stem from individual intention that is defined as a cognitive depiction of the person's willingness to try or to perform the behavior [65], which in turn depends on three global latent predictors: subjective norms, attitudes, and perceived behavioral control.

\subsubsection{Attitude}

The attitude is defined as the favorable or unfavorable feelings aligned with a particular action to perform a behavior. Further, attitude is stated as the positive or negative evaluation of performing that behavior. Previous studies found that there were two types of attitudes: a specific type and a general type. While the general type of attitude explicates the attitude toward environmental challenges, the specific type of attitude, on the other hand, indicates the attitude towards a specific green product $[66,67]$.

\subsubsection{Subjective Norm}

The subjective norm is theoretically determined as the perceived social pressure to engage or not in a behavior. Precisely, social pressure derives from the word of mouth opinion of friends and family members. In contemporary society, word of mouth has become vital in spreading and connecting individuals with the information about environmental degradation and has further stimulated individual pro-environmental behaviors [68].

\subsubsection{Perceived Behavioral Control}

In addition to the two predictors presented above, [39] defined the PBC as the "perceived ease or difficulty of performing a behavior", a factual statement of the projected basis of the combination of control beliefs and perceived power [69]. Accordingly, previous studies argued that the control beliefs and perceived power through different aspects, such as effort, cost, time, opportunities, and resources, perceived the inconvenience and availability that affected consumer purchase intentions $[70,71]$.

\subsection{Green Tourism Perception}

People are increasingly conscious of limited natural resources and the negative impacts of tourism when it comes to unidentified environmentally measures [72]. An individual's perception emerges from different perspectives, namely either an individual's attitude, social pressure, or an individual's concern about the environmental issues that convince them to perform a certain behavior that positively or negatively affects the individual in question. In addition, tourists' perceptions assume tourists' awareness and knowledge of environmental problems and challenges the world has been encountering, 
such as climate change. Understanding tourists' perceptions and reactions towards climate change and greenhouse gas emissions impacts individual behaviors towards environmental degradation in the tourism industry. Accordingly, their behavior effects positively their intention to adopt responsible and environmentally friendly travel itineraries $[73,74]$.

\subsection{Environmental Concern}

Environmental concern tends to strengthen an individual's emotional response regarding environmental issues. Moreover, it refers to the positive or negative attitude towards environmental challenges, environmental degradation, and climate change [75] and is well thought-out, such as "an affective attribute that exhibits the subject's compassion, worries, likes, and dislikes on the environment" [33]. That is why this variable is deemed a strong influential attitudinal factor [76] for pro-environmental behavior [77]. The majority of studies have considered environmental concern as a critical component and prominently assist in understanding individuals' engagement in environmental responsible behavior [78]. Many scholars criticized the measurement scale of environmental concern [79], particularly popular authors such as Stern et al., Dunlap et al., and Schultz [80-82]. In this study, environmental concern is included as a cognitive factor to the theory of planned behavior to measure its effect on tourists' attitudes and social influences for environmental protection and resource conservation.

\subsection{Environmentally Responsible Tourism Behavior}

Booming globally and locally, the pros and cons of tourism are inevitably recognized among all industries. Not only that, tourism contributes to the economic growth and cultural enhancement of a community's enrichment, but it is perceived as the most exposed sector to endanger the environment and the uneven allocation of benefits that could be harmful to the sustainability of the economy, environment, and society for some countries [83]. Thus, in order to face the world's challenging environmental problems such as climate change, scholars tend to study tourists' pro-environmental behaviors to provide tourism industry operators with considerable results to fill their knowledge gaps when it comes to understanding the sustainability of green tourism perception. Henceforth, research on environmental responsibility has been widely conducted and focused on tourists rather than other services related to pro-environmental behaviors. Therefore, in the course of this study, we defined our green tourism model and introduced our related hypotheses.

\section{Methodology}

\subsection{Model and Hypotheses}

Few studies considered developing countries, not to mention the case of small island states. Hence, we carried out this study on the island of the Turkish Republic of North Cyprus (TRNC) in the eastern Mediterranean region. This island reaps the advantages of mountainous, coastal, and cultural tourism. Its closest neighbor is Turkey to the north, which is the country from which the island received its recognition. Typically, the island's visitors prefer coastal tourism in Kyrenia and Magussa, while the city of Nicosia attracts keen tourists for cultural tourism, which maintains the rich Ottoman cultural heritage, with Venetian, Lusignan, and British historical values.

Our research model tends to examine and analyze international tourists' behavioral aspects towards the sustainability of green tourism and investigate the relevant interrelationships to explore their environmentally responsible tourism behavior as in Figure 1. Hence, we used the theory of planned behavior for its wide acceptance and successful prediction of pro-environmental behaviors and environmental behavioral intention [84-86]. Further, in the sustainability of green tourism context, we attempted to use the extended TPB model by adding two pro-social constructs to our model: the environmental concern (EC), and green tourism perception (GTP). 


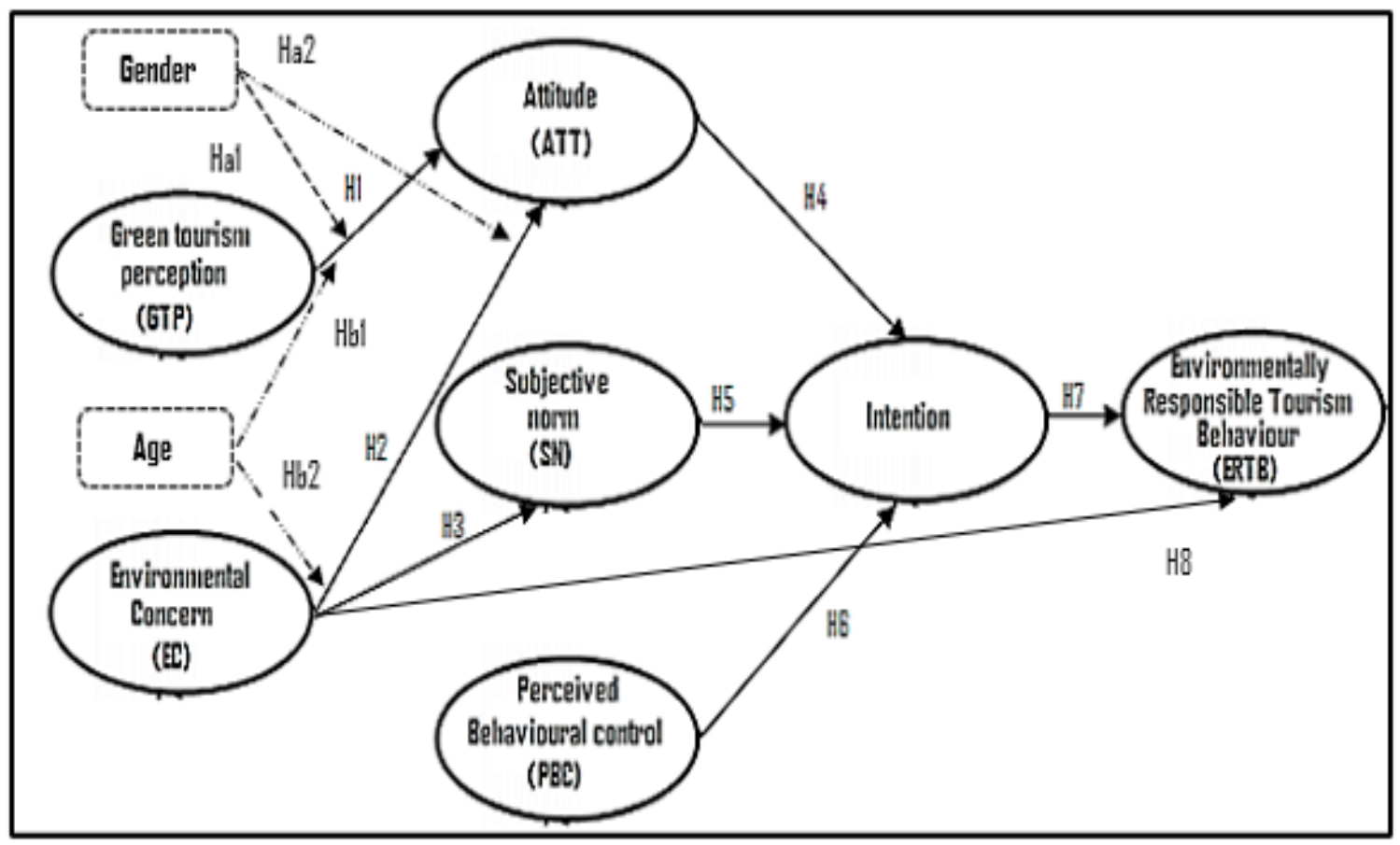

Figure 1. Green tourism research model.

\subsubsection{Interrelationship between Green Tourism Perception and Attitude}

Previous studies showed the positive effect of tourists' knowledge and perception of green product consumption on individuals of their pro-environmental behavior, which engenders their decision making [87]. Moreover, studies on the hospitality sector exhibited the significance of individual awareness and concerns of environmental matters, which determine their intention to visit and revisit green hotels [88]. Furthermore, there is a positive relationship between individual knowledge and an individual's pro-environmental behavior, which enhances the sustainability of green tourism participation around the globe [73]. Thus, in this study we proposed the following hypothesis:

Hypothesis 1 (H1). Tourists perceptions of sustainability of green tourism have a positive impact on their attitude to participate in environmentally responsible tourism behavior.

\subsubsection{Interrelationship between Environmental Concern and Attitude and Subjective Norms}

Previous research carried out on environmental protection showed positive impacts from both environmental concern and individual intentions to purchase green products [89,90]. Likewise, environmental concern also affects positively their attitude to purchase such green products [91]. The TPB framework extension by cognitive constructs has been extensively explored and similarly, in tourism, previous studies highlighted the strong and positive link of environmental concern towards perceived behavioral control, subjective norms, and attitudes in visiting green hotels [55]. Based on several conclusions in previous studies, in this study, we considered the direct effect of environmental concerns on attitudes and subjective norms. From the aforementioned discussion, we developed the following hypotheses:

Hypothesis 2 (H2). Environmental concern is positively related to tourists' attitudes to participate in environmentally responsible tourism behavior.

Hypothesis 3 (H3). Environmental concern is positively related to tourists' subjective norms to participate in environmentally responsible tourism behavior. 


\subsubsection{Interrelationship between Attitude and Environmentally Responsible Tourism Behavior}

As the tourism and hospitality sector paid more attention to environmental protection, several studies investigated tourists' general attitudes to participating in the sustainability of green tourism and specific attitudes in visiting and revisiting green hotels to participate in environmental protection [92]. According to Han et al., a tourist with a positive attitude towards visiting green hotels tends to have a positive intention to choose to stay at green hotels [93] and the likelihood to choose green hotels in practice [94]. Previous studies on environmentally responsible behaviors found evidence indicating positive relationships between attitude and green purchase intention $[95,96]$. Thus, we followed the literature to make the following conjecture:

Hypothesis 4 (H4). Tourists' attitudes have a positive link towards tourists' intentions to participate in environmentally responsible behaviors.

3.1.4. Interrelationship between Subjective Norms and Environmentally Responsible Tourism Behaviors

Some studies $[40,97,98]$ have shown the impact from subjective norms on behavioral intentions using the TPB. Thøgersen [99] showed a positive relationship between subjective social norms and pro-environmental behaviors. Previous studies show a positive impact of subjective norms on tourists' intention to visit green hotels [100] and consumers' intentions to purchase green products $[67,101]$. Similarly, we proposed the following statement:

Hypothesis 5 (H5). Tourists' subjective norms have a positive link towards tourists' intentions to participate in environmentally responsible behaviors.

\subsubsection{Interrelationship between Perceived Behavioral Control and Environmentally Responsible} Tourism Behavior

A previous study carried in China found a significantly positive impact of perceived behavioral control on sustainable consumption behaviors [70]. Studying green hotels, Chen and Tung [94] documented that $\mathrm{PBC}$ played a critical role in forming behavioral intentions. Similar results demonstrated a strongly positive relationship between perceived behavior and purchasing intention of green apparel products among millennials in India [102,103]. Based on empirical research, some researchers uncovered the negative and unrelated path of perceived behavioral control and behavioral intention [104]. Subsequently, contrasting views on perceived behavioral control required supplemental discussion and adjustments. Therefore, we proposed the following statement:

Hypothesis 6 (H6). Tourists perceived behavioral control has a positive link towards tourists' intentions to participate in environmentally responsible behaviors.

\subsubsection{Interrelationship between Intention and Environmentally Responsible Tourism Behavior}

According to [39], intention refers to a person's willingness to try to perform the actual behavior. However, it also indicates the "non-will" related to the factors (e.g., knowledge, time, and budget), which depicts the limited explanatory power of the theory of reasoned action. Thus, by using the TPB framework, academics find that perceived behavioral control, subjective norms, and attitude can be used in predicting behavioral intention. A previous study revealed positive impacts from the subjective norm, attitude, and PBC to the intention of using park-and-ride services facility in Malaysia [105] and affected positively tourists' visiting intentions [106]. Furthermore, intention is the immediate antecedent of actual behavior. Hence, a variety of behaviors were conducted in different contexts and a variety of terms were attributed to explain each behavior. To study the sustainability of green tourism, environmentally responsible tourism behavior was assigned and defined as a reaction of individual or group conduct of touristic activities towards environmental protection and 
promoting the sustainability of natural resources. Many terms were allocated interchangeably for this purpose, to include environmentally friendly behavior, pro-environmental behavior, eco-friendly behavior, green behavior, and environmentally conscious behavior. Thus, environmentally responsible tourism behavior is a tourist's actions and decision-making to either reduce or avoid environment destruction and personally conserve the environment and address environmental concerns in their activities. Authors in [107] observed positive impacts from subjective and moral norms, attitude, perceived behavioral control, and environmental concern on the adoption intention of buyers. Therefore, we propose the following statement:

Hypothesis 7 (H7). Tourists' intentions have a positive link towards individuals' environmentally responsible tourism behaviors.

3.1.7. Interrelationship between Environmental Concern and Environmentally Responsible Tourism Behavior

Environmentally responsible tourism behavior refers to the reaction of individuals and their decisions towards environmentally friendly products or services; herein, it refers to tourism as an industry held by practitioners for sustainable decision making in their business operations and pro-environmental resource management, it also refers to tourists as consumers to act by taking environmentally responsible measures while enjoying their experience. Tourists' understanding of environmental problems and climate change influence their behavior towards the environment [108]. Thus, the key to limiting environmental degradation and enhancing green growth among tourists and practitioners, tourism scholars are advised to further tackle this issue and promote environmental awareness and knowledge among individuals. Environmental concern is directly linked to environmentally responsible behavior. A previous study carried out on green hotels showed tourists' tendencies to offer premium prices for hotels' green practices [94,109]. Hence, we propose the following statement:

Hypothesis 8 (H8). Tourists' environmental concerns have a positive link towards individuals' environmentally responsible tourism behaviors.

\subsubsection{Age and Gender Effects}

Several studies considered demographic variables for individuals' behavioral intention; both gender and age were the most commonly considered and markedly refined the predictive power of the research model [63]. Hence, we attempted to uncover the moderating effects of both age and gender on environmental concerns, attitudes, and green tourism perception in this study. Along with environmental protection, previous studies document that women exhibited more concern about environmental degradation emotionally than men [77]. Additionally, females showed intention to recommend green hotels and showed willingness to pay higher prices to stay there and actively present their environmental concerns [110]. In addition, age differences could be as influential as gender for certain attitudinal behaviors. Moreover, age provoked a strong prediction of environmental concern [111]. Along the same line, younger individuals displayed a higher level of environmental awareness and knowledge than their elders [112]. People's degree of concern towards the environment is basically depending on gender differences when environmental behavior follows. Thus, this concern could begin at an early age. The literature has demonstrated that females are more concerned about the invisible danger in their surrounding environment and younger people are less influenced than older people. Thus, females express more environmental concern; as such, this reveal a positive influence on their willingness to offer to get green products than men [113]. Nevertheless, previous studies, for example [114], have found a significant moderating effect from both attitude and environmental concern to green purchasing behavior. Thus, two hypotheses were developed: 
Hypothesis a1 (Ha1). There is a positive moderating gender effect between green tourism perception and attitude.

Hypothesis b1 (Hb1). There is a positive moderating age effect between green tourism perception and attitude.

Hypothesis a2 (Ha2). There is a positive moderating gender effect between environmental concern and attitude.

Hypothesis b1 (Hb1). There is a positive moderating age effect between environmental concern and attitude.

\subsection{Instrument Development}

This study aims to investigate the behavioral aspects of international tourists towards the sustainability of green tourism, employing an extended framework of the theory of planned behavior (TPB). To do so, we designed the questionnaire to collect the necessary date. The questionnaire consisted of demographic characteristics of the respondents in the first section, while the second section consisted of items for each of the seven constructs in our study model. These are green tourism perception, environmental concern, attitudes, behavior, and intention to participate in the sustainability of green tourism, perceived behavioral control, and subjective norms. The specifics of the items for measuring each of the constructs are presented in Appendix A. The items measured for our constructs were adapted from a previous study and modified to suit the objectives of this study. The green tourism construct was measured with six items, which were adapted from [115]; environmental concern was measured through four items, which were adapted from [116]; attitudes was measured with five items, and adapted from [115]; behavior was also measured with five items, which were adapted from [115]; intention to participate in sustainability of green tourism was measured with four items; one item adapted from [115] and three items adapted from [116]; subjective norms was measured with three items, and adapted from [116]; while perceived behavioral control was measured with three items, which were adapted from Chuang et al. [86]. Subsequently, all the items were scaled with a five-point Likert scale, which ranged from 1 (strongly disagree) to 5 (strongly agree).

\subsection{Data Collection and Analysis}

This study used a simple random sample technique for data collection. The total number of five-star hotels was 24 hotels in the three main cities. The study sample data was collected from 20 five-star hotels in the three largest cities (Lefkosa, Girne, and Magusa) in North Cyprus as follows: Lefkosa 2, Girne 12, and Magusa 6. The study focused on five-star hotels, since they are the only ones that engage in ecological solutions. A structured questionnaire was employed in this study to collect information from the respondents. The study used disproportionate simple random sampling in which 20 questionnaires were handed over to each of the managers of each hotel for onward distribution to their customers. The managers handed the 20 questionnaires to the hotel guest randomly at the reception. This made it possible for us to retrieve about $98.75 \%$ (395) of the questionnaires distributed for further analysis.

In our analysis, we applied the two-stage Structural Equation Modelling (SEM) procedure [66] to examine whether our proposed hypothesized (green tourism research) model as stated in Figure 1 was appropriate. We first conducted Confirmatory Factor Analysis (CFA) to evaluate both the reliability and validity of our proposed model. We then estimated the full structural model, which was then used to test whether the hypotheses we set up in Section 3 held.

\section{Analysis and Findings}

\subsection{Demographic Analysis}

This study investigated whether there was any relationship among perception of green tourism, environmental concerns, subjective norms, attitude, perceived behavioral control, intention, and environmentally responsible behavior. We exhibit in Table 3 the response rate (a total of 
395 questionnaires were collected and were valid) and the total population of respondents by age, gender, marital status, education level, family size, and employment status. In our sample, $60.8 \%$ were male and $39.2 \%$ were female, inferring that our sample was male dominated. The demographic analysis showed that $39.7 \%$ and $29.8 \%$ were in the groups of $35-44$ and $45-54$ years old, respectively.

The population of this study was international tourists. In addition, in terms of level of education, diploma (61\%) was greater than bachelor's degree (31\%). Additionally, most of them had 2-3 persons in their family and most of them had full-time jobs (31.8\%) and others were self-employed in business $(28.5 \%)$, as presented in Table 1.

Table 1. The demographic characteristics of the sample.

\begin{tabular}{|c|c|c|c|}
\hline & & Frequency & Percent \\
\hline \multirow{2}{*}{ Gender } & Female & 155 & 39.2 \\
\hline & Male & 240 & 60.8 \\
\hline \multirow{7}{*}{ Age } & 18-24 years & 21 & 5.49 \\
\hline & 25-34 years & 49 & 12.4 \\
\hline & 35-44 years & 157 & 39.7 \\
\hline & $45-54$ years & 118 & 29.8 \\
\hline & 55-64 years & 57 & 14.6 \\
\hline & 55-64 years & 13 & 3.29 \\
\hline & 65 years or older & 1 & 0.25 \\
\hline \multirow{3}{*}{ Marital Status } & Single & 60 & 15.2 \\
\hline & Married & 219 & 55.4 \\
\hline & Divorced/Widowed & 116 & 29.4 \\
\hline \multirow{5}{*}{ Level of Education } & High school & 33 & 8.4 \\
\hline & Diploma & 200 & 50.6 \\
\hline & Bachelor's degree & 145 & 36.7 \\
\hline & Master's degree & 9 & 2.27 \\
\hline & Doctoral degree & 8 & 2.02 \\
\hline \multirow{4}{*}{ Family size } & 1 person & 20 & 5.06 \\
\hline & $2-3$ persons & 268 & 67.9 \\
\hline & 4-5 persons & 94 & 23.7 \\
\hline & More than 5 persons & 13 & 3.29 \\
\hline \multirow{6}{*}{ Employment status } & Student & 26 & 6.58 \\
\hline & Housewife & 71 & 2.35 \\
\hline & Unemployed & 8 & 17.9 \\
\hline & Business & 126 & 31.8 \\
\hline & Full-time & 152 & 28.5 \\
\hline & Part-time & 12 & 3.03 \\
\hline
\end{tabular}

\subsection{Descriptive Analysis}

Employing a five-point Likert scale that ranged from 1 (strongly disagree) to 5 (strongly agree), we found that the mean and standard deviation scores of all the variables we used to measure international tourists in this study varied from 3.04 to 4.15 (and 0.55 to 0.89 ), inferring that all the variables of international tourists were in a moderate perception. The mean and standard deviation of environmental concern were 4.04 and 0.89 , respectively, indicating moderate to average environmental concern. Green tourism perception was 3.04 (0.56), demonstrating the neutral to average in terms of green tourism. Attitude (3.43 and 0.55), environmentally responsible tourism behavior (4.01 and 0.80 ), subjective norm (4.06 and 0.70), perceived behavioral control (4.00 and 0.79), intention (4.15 and 0.84) indicated the respondents had moderate to average intention among international tourists, as shown in Table 2. In general, we found that 5 out of 7 variables being used in our study obtained high mean scores (higher than 4), and the rest had average mean scores (between 2 and 4). 
Table 2. Descriptive statistics: Mean and standard deviation.

\begin{tabular}{ccc}
\hline Constructs & Mean & Standard Deviation \\
\hline Green tourism perception & 3.04 & 0.56 \\
Environmental concern & 4.04 & 0.89 \\
Attitude & 3.43 & 0.55 \\
Environmentally responsible tourism behavior & 4.01 & 0.8 \\
Subjective norm & 4.06 & 0.7 \\
Perceived behavioral control & 4 & 0.79 \\
Intention & 4.15 & 0.84 \\
\hline
\end{tabular}

\subsection{Convergent Validity and Discriminant Validity}

We exhibited the factor loading, and the Average Variance Extracted (AVE) and composite reliability (CR); we also presented the Cronbach's alpha for each construct, as seen in Table 3. In addition, Table 4 shows the measurement of model discriminant validity, which can be used to test for the reliability and convergent discriminant validities. We followed the suggestions of Hair et al. [117] to set the conditions that all loadings must be higher than 0.40 ; the AVE was higher than $0.50[118,119]$, and these requirements were satisfied for all constructs, as shown in Table 3. From Table 3, the values of the AVE for all the constructs ranged from 0.785 to 0.973 , concluding convergent validity for all the constructs. In addition, we employed the cross-loading measurement criteria [120] to test for discriminant validity for the respective constructs.

Table 3. Convergent validity and discriminant validity.

\begin{tabular}{|c|c|c|c|c|}
\hline Construct & Factor Loading & $\begin{array}{l}\text { Average Variance } \\
\text { Extracted (AVE) }\end{array}$ & $\begin{array}{c}\text { Composite } \\
\text { Reliability (CR) }\end{array}$ & $\begin{array}{c}\text { Cronbach's Alpha } \\
(\alpha)\end{array}$ \\
\hline \multirow{4}{*}{$\begin{array}{l}\text { Green tourism } \\
\text { perception }\end{array}$} & 0.909 & \multirow{4}{*}{0.788} & \multirow{4}{*}{0.919} & \multirow{4}{*}{0.911} \\
\hline & 0.878 & & & \\
\hline & 0.873 & & & \\
\hline & 0.891 & & & \\
\hline \multirow{4}{*}{$\begin{array}{l}\text { Environmental } \\
\text { concern }\end{array}$} & 0.950 & \multirow{4}{*}{0.905} & \multirow{4}{*}{0.972} & \multirow{4}{*}{0.965} \\
\hline & 0.958 & & & \\
\hline & 0.946 & & & \\
\hline & 0.953 & & & \\
\hline \multirow{4}{*}{ Attitude } & 0.777 & \multirow{4}{*}{0.611} & \multirow{4}{*}{0.991} & \multirow{4}{*}{0.824} \\
\hline & 0.765 & & & \\
\hline & 0.767 & & & \\
\hline & 0.818 & & & \\
\hline \multirow{4}{*}{ Intention } & 0.968 & \multirow{4}{*}{0.930} & \multirow{4}{*}{0.976} & \multirow{4}{*}{0.975} \\
\hline & 0.966 & & & \\
\hline & 0.952 & & & \\
\hline & 0.972 & & & \\
\hline \multirow{3}{*}{ Subjective norm } & 0.834 & \multirow{3}{*}{0.729} & \multirow{3}{*}{0.825} & \multirow{3}{*}{0.722} \\
\hline & 0.875 & & & \\
\hline & 0.853 & & & \\
\hline
\end{tabular}


Table 3. Cont.

\begin{tabular}{|c|c|c|c|c|}
\hline Construct & Factor Loading & $\begin{array}{l}\text { Average Variance } \\
\text { Extracted (AVE) }\end{array}$ & $\begin{array}{c}\text { Composite } \\
\text { Reliability (CR) }\end{array}$ & $\begin{array}{c}\text { Cronbach's Alpha } \\
(\alpha)\end{array}$ \\
\hline \multirow{3}{*}{$\begin{array}{c}\text { Perceived } \\
\text { behavior control }\end{array}$} & 0.709 & \multirow{3}{*}{0.586} & \multirow{3}{*}{0.931} & \multirow{3}{*}{0.815} \\
\hline & 0.935 & & & \\
\hline & 0.618 & & & \\
\hline \multirow{4}{*}{$\begin{array}{l}\text { Environmentally } \\
\text { responsible } \\
\text { tourism behavior }\end{array}$} & 0.873 & \multirow{4}{*}{0.741} & \multirow{4}{*}{0.893} & \multirow{4}{*}{0.844} \\
\hline & 0.868 & & & \\
\hline & 0.849 & & & \\
\hline & 0.853 & & & \\
\hline
\end{tabular}

Table 4. The measurement of model discriminant validity.

\begin{tabular}{cccccccc}
\hline Constructs & $\mathbf{1}$ & $\mathbf{2}$ & $\mathbf{3}$ & $\mathbf{3}$ & $\mathbf{4}$ & $\mathbf{5}$ & $\mathbf{6}$ \\
\hline Attitude & 0.611 & & & & & & \\
\hline Environmental concern & 0.134 & 0.905 & & & & & \\
\hline Green tourism perception & 0.012 & 0.001 & 0.788 & & & & \\
\hline Intention & 0.545 & 0.191 & 0.001 & 0.93 & & & \\
\hline $\begin{array}{c}\text { Environmentally responsible } \\
\text { tourism behavior }\end{array}$ & 0.247 & 0.18 & 0.007 & 0.204 & 0.741 & & \\
\hline Subjective norms & 0.038 & 0.007 & 0.039 & 0.001 & 0.024 & 0.729 & \\
\hline Perceived behavioral control & 0.007 & 0 & 0.007 & 0.004 & 0.001 & 0.372 & 0.586 \\
\hline
\end{tabular}

Further results, as displayed in Table 4, showed that the value of the discriminant validity was satisfied for each construct.

\subsection{Model Testing, Path Coefficient, and Level of Significance}

According to [121], the measurement model, the structural model, and model fit-goodness of fit index (GFI), normed fit index (NFI), comparative fit index (CFI), Tucker-Lewis Index (TLI), and root mean square error of approximation (RMSEA) - estimates must be well above the recommended values by [122] and in this study the CFA presented an acceptable model fit $\left(X^{2}=483.40\right.$, and $\mathrm{df}=254$, $X^{2} / \mathrm{df}=1.90$; goodness of fit index $(\mathrm{GFI})=0.988$; normed fit index $(\mathrm{NFI})=0.944$; incremental fit index $(\mathrm{IFI})=0.972$; Tucker-Lewis index $(\mathrm{TLI})=0.967$; comparative fit index $(\mathrm{CFI})=0.972$; standardized root mean square residual $(S R M R)=0.034$; root mean square error of approximation $($ RMSEA $)=0.048$, $p \leq 0.05$; that is, RMSEA was less than 0.08, as shown in Table 5).

Table 5. Model fit statistics.

\begin{tabular}{lcccccccc}
\hline Criteria & X2 & Df & P & X2/df & RMSEA & GFI & TLI & CFI \\
\hline Coefficient & 483.4 & 254 & $<0.001$ & 1.9 & 0.048 & 0.988 & 0.967 & 0.972 \\
\hline
\end{tabular}

The second step after model testing was to estimate the original coefficients $(\beta)$ and $p$-values of the structural model. This was to determine the model fit of any given conceptual framework. Thus, this study employed the structural equation modelling by using Jeffreys's Amazing Statistics Program (JASP 10.0.2.0) for variance-based structural equation modelling and tests of model fit.

As listed in Table 5 , the main factors included the relationship between green tourism perception and attitude $(\beta=0.120, p<0.01)$, environment concern and attitude $(\beta=0.370, p<0.01)$, environment concern and environmentally responsible tourism behavior $(\beta=0.282, p<0.01)$, which were positive, and significant paths and subjective norms $(\beta=0.089)$, which was insignificant. Additionally, among the 
factors influencing the relationship between subjective norms and behavioral intention $(\beta=-0.173$, $p<0.01)$ and attitude and behavioral intention $(\beta=0.77, p<0.01)$, which showed that there was a significant positive effect on the relationship between subjective norms and attitude, and attitude and behavioral intention. However, perceived behavior control and behavioral intention $(\beta=-0.02)$ showed no significant effect. Additionally, the factors influencing the relationship between behavioral intention and environmentally responsible tourism behavior $(\beta=0.452, p<0.01)$ had a significant and positive effect. Therefore, all paths except $\mathrm{H} 3$ and $\mathrm{H} 6$ were not supported. The results indicated that the six endogenous variables were useful and significant to determine the core construct of the TPB model, as shown in Table 6.

Table 6. Path coefficients and level of significance.

\begin{tabular}{cccccc}
\hline Hy. & Effects & Original Coefficient & t-Value & $p$-Value & Paths \\
\hline H1 & GTP $\rightarrow$ ATT & 0.12 & 2.536 & 0.011 & Supported \\
H2 & EC $\rightarrow$ ATT & 0.37 & 6.544 & 0 & Supported \\
H3 & EC $\rightarrow$ SN & 0.089 & 1.63 & 0.103 & Not supported \\
H4 & ATT $\rightarrow$ Intention & 0.774 & 38.08 & 0 & Supported \\
H5 & SN $\rightarrow$ Intention & -0.173 & -3.622 & 0 & Supported \\
H6 & PBC $\rightarrow$ Intention & -0.02 & -0.418 & 0.676 & Not supported \\
H7 & Intention $\rightarrow$ ERTB & 0.452 & 8.237 & 0 & Supported \\
H8 & EC $\rightarrow$ ERTB & 0.282 & 4.057 & 0 & Supported \\
\hline
\end{tabular}

\subsection{Moderation Effects of Control Variables-Age and Gender}

This study tested how the age and gender as demographic variables moderated the effect between the two constructs-moderation effects of age on green tourism perception and attitude, and gender on green tourism perception and attitudes were examined. In addition, moderation effects of age on environmental concerns and attitude, and gender on environmental concerns and attitude were examined.

The outcomes of moderation effects in Table 7 indicated that the construct of age was moderating the interrelationship effect between environmental concerns and attitude $(\beta=0.268, z=6.250, p<0.001)$, and the construct of age was moderating the interrelationship effect between green tourism perception and attitude $(\beta=0.094, \mathrm{z}=1.98, p<0.01)$. In addition, the result in Table 7 showed that the socio-demographic variable of gender moderated the relationship between environmental concerns and attitude. Therefore, the result of path coefficient indicated that gender had a high moderate effect on the relationship between environmental concerns and attitude $(\beta=0.094, z=1.99, p<0.05)$, and the result of path coefficient indicated that gender had a high moderate effect on the relationship between green tourism perception and attitude $(\beta=0.226, \mathrm{z}=6.23, p<0.001)$.

Table 7. Moderation estimates—age and gender.

\begin{tabular}{|c|c|c|c|c|c|}
\hline Нy. & Effect & Estimate & SE & $\mathbf{Z}$ & $\mathbf{P}$ \\
\hline & \multicolumn{5}{|c|}{ Gender } \\
\hline Ha1 & $\mathrm{GTP} \rightarrow \mathrm{ATT}$ & 0.266 & 0.043 & $6.23^{* * *}$ & $<0.001$ \\
\hline \multirow[t]{2}{*}{$\mathrm{Ha} 2$} & $\mathrm{EC} \rightarrow \mathrm{ATT}$ & 0.094 & 0.047 & 1.99 * & 0.046 \\
\hline & \multicolumn{5}{|c|}{ Age } \\
\hline Hb1 & $\mathrm{GTP} \rightarrow \mathrm{ATT}$ & 0.094 & 0.094 & $1.98^{*}$ & 0.047 \\
\hline $\mathrm{Hb} 2$ & $\mathrm{EC} \rightarrow \mathrm{ATT}$ & 0.268 & 0.043 & $6.250 * * *$ & $<0.001$ \\
\hline
\end{tabular}

Figure 2 indicates that the following hypotheses; $\mathrm{H} 1, \mathrm{H} 2, \mathrm{H} 4, \mathrm{H} 7$ and $\mathrm{H} 8$ were positively significant. Yet, $\mathrm{H} 5$ was found negatively significant. However, H3 and H6 found insignificant. 


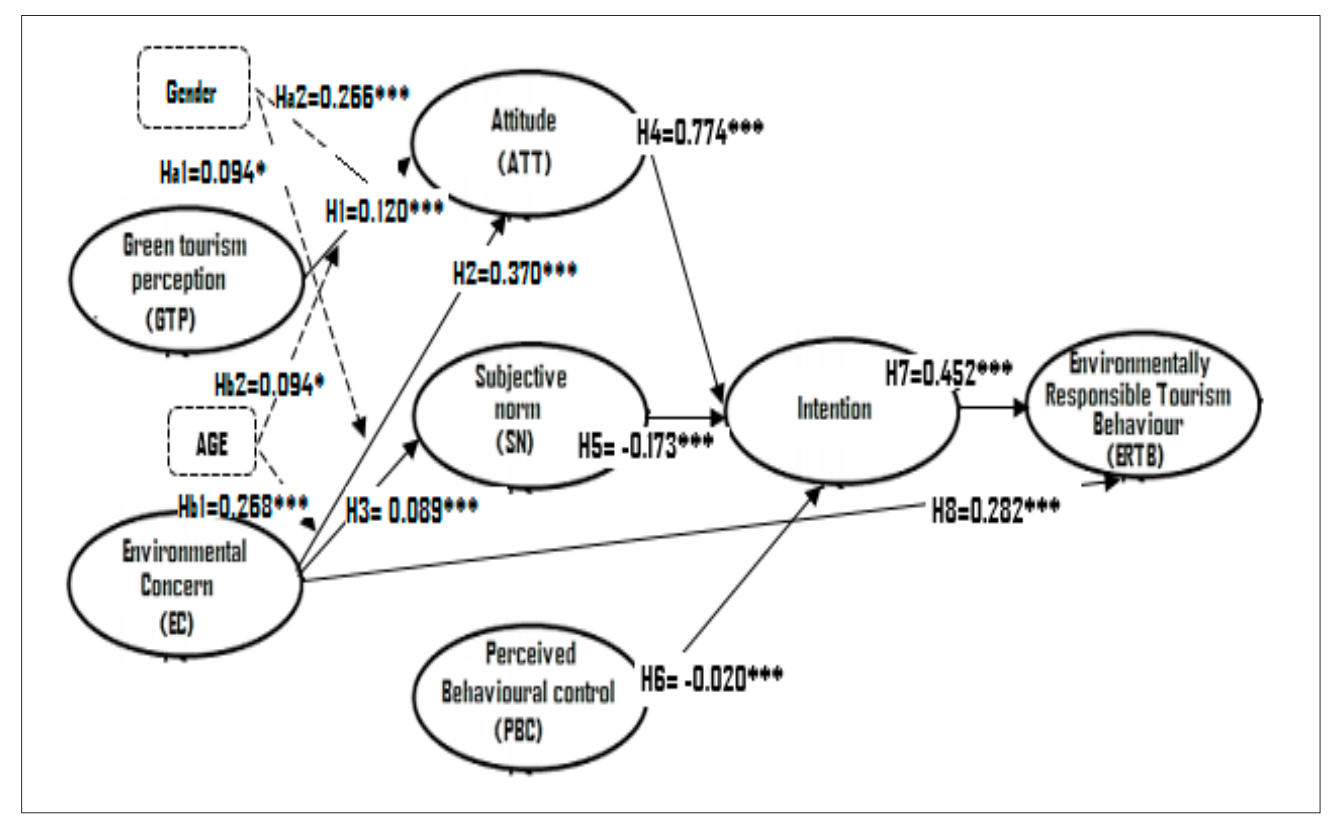

Figure 2. Results of hypothesis test.

\section{Discussion and Conclusion Remarks}

\subsection{Discussion}

Most of the literature in tourism sustainability aims at studying in economically advanced countries, and very few studies investigate developing countries, not to mention a small island state. Additionally, investigating the behavioral aspects of consumers for green growth and their awareness about the environment and knowing the role consumers are playing in ameliorating environmental degradation reduction is an important topic in tourism. Thus, to bridge the gap in the literature, this study contributes to the literature by investigating the innovative aspect of consumer behavior towards environmental degradation reduction in North Cyprus, a small Island state. To the best of our knowledge, our study is the first paper in the literature to investigate the innovative aspect of consumer behavior towards environmental degradation reduction in North Cyprus. Our study also investigates the moderating role of both age and gender of customers in strengthening the understanding of consumer behavior.

We applied the Theory of Planned Behavior (TPB) in our study to examine the contribution of consumers' attitudes, subjective norms, and perceived behavioral control on their intentions to participate in sustainability of green tourism and conduct environmentally responsible tourism behaviors. We then extended the theory of planned behavior to include the other two constructs, namely environmental concern and sustainability of green tourism perception, to the original constructs of the TPB model (attitude, subjective norms, perceived behavioral control, intention, and behavior). Firstly, we conceptualized all the hypotheses based on the foundations of the literature to get a more robust understanding of tourists' perceptions towards sustainability of green tourism and consumers' environmental concerns, which has a direct and indirect impact on tourists' behavior. On the one hand, EC is linked to consumers' subjective norms and attitudes. On the other hand, EC is directly linked to environmentally responsible tourism behavior. Secondly, consumers' intentions to participate in the sustainability of green tourism is then influencing tourists' behaviors for environmentally responsible tourism participation. Thus, these relationships investigate tourists' behavioral aspects of environmental degradation reduction that indirectly contribute to sustainable development while developing environmentally innovative initiatives among tourists to achieve green growth. Lastly, we presented the moderating effect of age and gender on both relationships, environmental concern 
and attitude, green tourism perception, and attitude. We then provided empirical support to test all the hypotheses developed in our study.

Realizing the significance of the TPB model since it has been widely used in previous studies to illustrate the relationship between consumers' environmental behaviors and environmental intentions $[39,52,85]$. Consequently, while examining the tourism industry, our ultimate objective was to investigate the behavioral aspects of tourists towards environmental challenges and their decision-making impacts to achieve green growth and environmental degradation reduction in tourism destinations.

We believe that as human beings on this globe, we all emotionally engage in a direct responsibility to be surrounded by our environmental consciousness to then contribute broadly to ameliorating the reduction of environmental degradation. Thus, we follow [115] to shed light on tourists' perceptions of sustainability of green tourism in order to determine their attitudes and integrate environmentally responsible tourism behavior in this model, which is immediately anticipated by their intention to partake in sustainability of green tourism. Thus, we also adhere to [116] and cover the three relationships added to the model including environmental concern as an antecedent to attitude, subjective norms, and environmentally responsible tourism behavior. We strengthened our study with two control variables, and gave significant insight to the model by including both age and gender in the model.

The findings from our study infer that attitude has a positive direct relationship with intention, representing the positive action of the tourist towards their intention to participate in sustainability of green tourism. Thus, this is consistent with some previous studies, which emphasized that the particular action and social influence of an individual with respect to their intention to participate in activities could be either positive or negative $[46,52,85,86]$. Meanwhile, the third construct in the TPB model, which is the perceived behavioral control, was not found to be significant. Thus, on the other hand, our findings contradicted some studies that pointed out that the degree of control of an individual to perform specific behavior directly impacts their intention to perform the behavior $[46,86]$. However, some studies were consistent with our findings. [115,116] Next to that, the interrelationship between attitude and green tourism perception showed a positive and significant link. This implies that the perception of tourist on sustainability of green tourism significantly influences their attitude towards the environment [115]. Similarly, the interrelationship between environmental concern and attitude was found to be positively and significantly influential and identical to the interrelationship between environmental concern and environmentally responsible tourism behavior, entailing that tourists' environmental concerns are directly linked to their responsible behavior and their attitude to participate in sustainability of green tourism. However, the interrelationship between environmental concern and the subjective norm was not found significant. Thus, we could link this result to the lack of environmental concern among the individual social influence such as family members and friends.

The interrelationships between the three main constructs (attitude, subjective norms, and perceived behavioral control) in the TPB model [39] and the intention in participating in sustainability of green tourism revealed a positive and significant impact of attitude, while subjective norm revealed a negative and significant impact. Similarly, the perceived behavioral control demonstrated a negative impact, which is an interesting result. This aligns with [123], which found the PBC to be an insignificant determinant in purchasing housing in China and aligns with [124] that found no significant influence of PBC towards green product purchasing intention in Kenya. This implies strong pressure from others and a lack of self-confidence and self-sufficiency while deciding a behavior. Finally, the interrelationship between intention and environmentally responsible tourism behavior was found to be positively linked. Hence, we successfully mitigate the usefulness and predictability of the extended theory of planned behavior among the behavioral aspects of an individual in the tourism concept and for the specific environmentally responsible behavior. Overall, tourists' environmentally responsible behaviors demonstrate their intent to limit environmental degradation and to contribute to achieving green growth and likely to find innovative ideas towards protecting the environment while enjoying 
their tourism experience [115]. Age and gender were found to positively moderate both relationships, environmental concern, and attitude, as well as green tourism perception and attitude.

\subsection{Study Implications}

Our study developed a framework that attempts to provide more understanding of the behavioral intentions of the tourists that are environmentally conscious. In addition, our study recommends that the perception of the tourist on sustainability of green tourism and their environmental concern can be added to the theory of planned behavior to reveal more insights of international tourists towards ameliorating environmental degradation reduction.

The main theoretical implication of this study is the provision of respectively valuable contributions to miscellaneous arenas, most particularly coupled with the internationalization of tourism industry [7-12]. Thus, our study provides a direction for more empirical research on the extent of the sustainability of tourism and green development. Specifically, another significant contribution of our study is the empirical support for the significant effect of tourist perception on sustainability of green tourism and their environmental concern on the tourists' attitude [21,115]. Similarly, the significant influence of tourists' intentions to participate in sustainability of green tourism on the tourist's individual behavior was established in this study [11,116]. The understanding of consumer perception of green tourism and their environmental concern through subjective norms, attitude, and perceived behavioral control towards the individual tourist behavior and intention to participate in green development is among the contributions of this study.

From a practical perspective, the hotel managers should improve the medium of communication on the significance of the green environment to their guests and establish a mechanism of receiving feedback related to the environmental practices of hotels operators within their journey. Meanwhile, the environmental concern of international tourists, which was found not to be influenced by the subjective norms in our study, is an indication that the environmental concern of an individual does not have an impact on the decision of an individual based on their social influence. Thus, there is a need for hotel management to elaborate a strategy of enhancing the environmental awareness among their guests, as this will have an influence on the achievement of a green environment at large.

Lastly, we notice that the environmental concern of the international tourist, was found to have a positive and significant effect on individual environmentally responsible tourism behavior, hence, it becomes imperative for all the stakeholders (government, private sector, entrepreneurs, and marketers) to develop public programs that will showcase how being an environmentally responsible person can assist in limiting the hostile impact of tourism on the environment.

\subsection{Limitation and Directions for Future Studies}

There is a little research that is devoid of limitations, and our study is no exception. In our data collection, the customers at five-star hotels in North Cyprus were used, which imposed a limitation on the study and could limit the generalizability of our results to another context. Therefore, an extension of our study is to use our model on customers that are lodged in real green hotels. In addition, because the study was carried out in conventional hotels, future research could include a comparative study between the customers of conventional hotels and green hotels to see whether there is any difference in their behavior towards green growth, as well as their awareness about the environment, which undoubtedly will play a significant role in environmental degradation reduction. Moreover, future studies can investigate the mediating role of the consumer's environmental awareness in the relationship between their behavioral intentions towards environmental degradation reduction. Lastly, the moderating influence of the types of consumers (business or leisure) in the relationship between the behavior and contribution to environmental degradation reduction will be of significant interest. 


\section{Conclusions}

This research envisages an overall perception of green tourism among international tourists regarding the amelioration of degradation reduction of the environment. It also examines the sustainability approach of green tourism on the island and its impact on the behavioral aspects of international tourists lodging in five-star hotels in North Cyprus, a small island state. Noting that over the past few years, hotels, particularly in small-island destination, are increasingly starting to involve ecological solutions to promote green tourism and impel green tourism practices because of their unique characteristics that consider the limited resources and natural conditions engendering environmental degradation due to tourism attraction and recent growth on the island. Briefly, we point out in this study both main research objectives namely, sustainability of green tourism and environmentally responsible tourism behavior. The sustainability of green tourism is a priority in the tourism industry and hence it is essential to take account of behaviors surrounding practices in tourism. Thus, it is very important for scholars to conduct empirical studies on the subtle details of green tourism growth at the local and international scale, and investigate hotels' operators and tourists' implications in the green tourism sector and awareness of green tourism principles, either at the local scale or the international scale. The sustainability of green tourism in small islands requires research to develop insights that could be helpful in protecting scarce natural resources and largely encourage international tourists to show environmentally responsible tourism behavior when enjoying their travel experience, especially in nature-based destinations.

Furthermore, according to the authors' knowledge, the behavioral aspects examined using the theory of planned behavior that showed interesting predictions of international tourists' behavioral facets in the context of pro-environmental behavior of international tourists in their contribution to green growth has not been exhaustively investigated, most especially in a small island state like North Cyprus. Thus, in our study, we addressed this identified lapse and suggested several implications for tourism industry practitioners, hotels management and stakeholders, and marketing management operators to take into consideration.

Hence, we contributed to the discourse of our study in presenting acumens of an approach of sustainability of green tourism perception of international tourists, which value the interconnection of the three pillars correspondingly: the economic benefits on local community, environmental degradation reduction, and social participation. Consequently, the valuable contribution of this study to the literature is noticeable and calls for practitioners to adopt managerial measures equivalent to green management operations. Environmental concern, referred to as a cognitive psycho-metric, and the knowledge of environmental problems, showed an important effect on environmentally responsible tourism behavior directly and indirectly throughout international tourists' intentions to partake in the sustainability of green tourism behavior in North Cyprus. Henceforth, the greater sustainability measures are taken and considered in practice, the more unfailing experiences of international tourists are sustainably achieved. Thus, hotels managers specifically and tourism industry generally are imperatively contributing to environmental degradation reduction when targeting the best ways to ameliorate their practices based on a greener structure.

Author Contributions: Conceptualization, S.I.-L.; Methodology, S.I.-L.; software, S.I.-L.; formal analysis, S.I.-L.; data curation, H.R.; writing-original draft preparation W.-K.W.; writing—review and editing, W.-K.W.; supervision, H.R. All authors have read and agreed to the published version of the manuscript.

Funding: This research received no external funding.

Acknowledgments: The authors would like to thank the Editor, Editor Assistant for their guidance and follow-up. Also, authors would like to thank the anonymous referee for their valuable comments that's enhance our paper to appear in its current format.

Conflicts of Interest: The authors declare no conflict of interest. 


\section{Appendix A}

\section{GREEN TOURISM PERCEPTION}

1. Consuming local food helps reduce carbon emission

2. Reducing use of disposable products helps reduce carbon emission

3. Wearing lightweight clothing helps reduce carbon emission

4. Carrying your own toothbrush and towels helps reduce carbon emission

5. Taking public transportation can reduce carbon emission

6. The carbon emission of different types of hotels is different

\section{ENVIRONMENTAL CONCERN}

7. I am very concerned about the state of the world's environment

8. I am willing to reduce my consumption to help protect the environment

9. Major social changes are necessary to protect the natural environment

10. Major political change is necessary to protect the natural environment

\begin{tabular}{|c|c|c|}
\hline \multicolumn{3}{|c|}{ ATTITUDES } \\
\hline & Green tourism can ensure the quality of the environment & \multirow{5}{*}{ [115] } \\
\hline & Green tourism can promote the local tourism industry & \\
\hline & Green tourism has educational meaning & \\
\hline & Green tourism can enhance my travel experiences & \\
\hline & Green tourism can enhance my knowledge of resource conservation & \\
\hline \multicolumn{3}{|c|}{ ENVIRONMENTALLY RESPONSIBLE TOURISM BEHAVIOUR } \\
\hline & I choose to take public transportation if available & \multirow{5}{*}{ [115] } \\
\hline & I carry my own water bottles when traveling & \\
\hline & I carry my own shopping bags when traveling & \\
\hline & I carry my own toothbrush and towels when traveling & \\
\hline & I choose to purchase souvenirs with less packaging & \\
\hline \multicolumn{3}{|c|}{ INTENTION OF PARTICIPATION IN GREEN TOURISM } \\
\hline & I will follow green tourism principles when I am traveling & [115] \\
\hline & I intend to stay in green hotels next time because of its positive environmental contribution & \multirow{3}{*}{ [116] } \\
\hline & I plan to stay in green hotels rather than conventional hotels & \\
\hline 24. & I will consider switching to green tourism for ecological reason & \\
\hline \multicolumn{3}{|c|}{ SUBJECTIVE NORM (SN) } \\
\hline 25. & My family think that I should participate in green tourism & \multirow{3}{*}{ [116] } \\
\hline 26. & My close friends think that I should participate in green tourism & \\
\hline 27. & Most people who are important to me think I should participate in green tourism & \\
\hline \multicolumn{3}{|c|}{ PERCEIVED BEHAVIORAL CONTROL (PBC) } \\
\hline 28. & Whether or not I participate in green tourism when traveling is entirely up to me. & \multirow[b]{2}{*}{ [86] } \\
\hline 29. & I am confident that if I want, I can participate in green tourism when traveling. & \\
\hline
\end{tabular}




\section{References}

1. Ahmad, F.; Draz, M.; Su, L.; Ozturk, I.; Rauf, A. Tourism and Environmental Pollution: Evidence from the One Belt One Road Provinces of Western China. Sustainability 2018, 10, 3520. [CrossRef]

2. Chan, E.S.; Wong, S.C. Motivations for ISO 14001 in the hotel industry. Tour. Manag. 2006, 27, 481-492. [CrossRef]

3. Gössling, S. Global environmental consequences of tourism. Glob. Environ. Chang. 2002, 12, $283-302$. [CrossRef]

4. Freudenburg, W.R.; Muselli, V. Reexamining climate change debates: Scientific disagreement or scientific certainty argumentation methods (SCAMs)? Am. Behav. Sci. 2013, 57, 777-795. [CrossRef]

5. Hill, J.L.; Gale, T. (Eds.) Ecotourism and Environmental Sustainability: Principles and Practice; Ashgate Publishing, Ltd.: Surrey, UK, 2009; ISBN 9780754672623.

6. Hall, C.M. A typology of governance and its implications for tourism policy analysis. J. Sustain. Tour. 2011, 19, 437-457. [CrossRef]

7. ER, E. Energy conservation and retrofitting potential in Hellenic hotels. Energy Build. 1996, 24, 65-75.

8. Arena, A.P.; de Rosa, C. Life cycle assessment of energy and environmental implications of the implementation of conservation technologies in school buildings in Mendoza, Argentina. Build. Environ. 2003, 38, 359-368. [CrossRef]

9. Blengini, G.A. Life cycle of buildings, demolition and recycling potential: A case study in Turin, Italy. Build. Environ. 2009, 44, 319-330. [CrossRef]

10. Gössling, S.; Hall, C.M.; Scott, D. Tourism and Water; Channel View: Bristol, UK, 2015.

11. Xydis, G.; Koroneos, C.; Polyzakis, A. Energy and exergy analysis of the Greek hotel sector: An application. Energy Build. 2009, 41, 402-406. [CrossRef]

12. Asmelash, A.G.; Kumar, S. Assessing progress of tourism sustainability: Developing and validating sustainability indicators. Tour. Manag. 2019, 71, 67-83. [CrossRef]

13. UNEP UNWTO. Making Tourism More Sustainable-A Guide for Policy Makers; UNEP UNWTO: New York, NY, USA, 2005.

14. Yu, C.P.; Chancellor, H.C.; Cole, S.T. Measuring residents' attitudes toward sustainable tourism: A reexamination of the sustainable tourism attitude scale. J. Travel Res. 2011, 50, 57-63. [CrossRef]

15. Line, N.D.; Hanks, L.; Miao, L. Image matters: Incentivizing green tourism behavior. J. Travel Res. 2018, 57, 296-309. [CrossRef]

16. Kirkby, J.; Curtius, J.; Almeida, J.; Dunne, E.; Duplissy, J.; Ehrhart, S.; Franchin, A.; Gagné, S.; Ickes, L.; Kürten, A.; et al. Role of sulphuric acid, ammonia and galactic cosmic rays in atmospheric aerosol nucleation. Nature 2011, 476, 429-433. [CrossRef] [PubMed]

17. Giddings, B.; Hopwood, B.; Mellor, M.; O’Brien, G. Back to the city: A route to urban Sustainability. In Future Forms and Design for Sustainable Cities; Architectural Press: Oxford, UK, 2006; pp. 24-41.

18. Mihalic, T. Sustainable-responsible tourism discourse-Towards 'responsustable' tourism. J. Clean. Prod. 2016, 111, 461-470. [CrossRef]

19. Singh, N.; Cranage, D.A.; Nath, A. Estimation of GHG emission from hotel industry. Anatolia 2014, 25, 39-48. [CrossRef]

20. Chen, H.; Bernard, S.; Rahman, I. Greenwashing in hotels: A structural model of trust and behavioral intentions. J. Clean. Prod. 2019, 206, 326-335. [CrossRef]

21. Tölkes, C. Sustainability communication in tourism-A literature review. Tour. Manag. Perspect. 2018, 27, 10-21. [CrossRef]

22. Hargreaves, T. Practice-ing behaviour change: Applying social practice theory to pro-environmental behaviour change. J. Consum. Cult. 2011, 11, 79-99. [CrossRef]

23. Moser, A.K. Thinking green, buying green? Drivers of pro-environmental purchasing behavior. J. Consum. Mark. 2015, 32, 167-175. [CrossRef]

24. Zientara, P.; Zamojska, A. Green organizational climates and employee pro-environmental behaviour in the hotel industry. J. Sustain. Tour. 2018, 26, 1142-1159. [CrossRef]

25. Song, Z.; Soopramanien, D. Types of place attachment and pro-environmental behaviors of urban residents in Beijing. Cities 2019, 84, 112-120. [CrossRef] 
26. Tiago, T.; Faria, S.D.; Cogumbreiro, J.L.; Couto, J.P.; Tiago, F. Different Shades of Green on Small Islands, Island Studies Journal, 2016. Available online: https://www.islandstudies.ca/sites/default/files/ISJ-11-2MS343-Tiago-et-al_0.pdf (accessed on 12 July 2020).

27. Raharjo, K. The role of green management in creating sustainability performance on the small and medium enterprises. Manag. Environ. Qual. Int. J. 2019, 30, 557-577. [CrossRef]

28. Peattie, K.; Charter, M. Green marketing. In The Marketing Book; 2003; Volume 5, pp. 726-755. Available online: https://www.sciencedirect.com/science/article/pii/B9780750685665500327?via\%3Dihub (accessed on 12 July 2020).

29. Do Paco, A.; Raposo, M. "Green" segmentation: An application to the Portuguese consumer market. Mark. Intell. Plan. 2009, 27, 364-379. [CrossRef]

30. Li, G.; Li, W.; Jin, Z.; Wang, Z. Influence of Environmental Concern and Knowledge on Households' Willingness to Purchase Energy-Efficient Appliances: A Case Study in Shanxi, China. Sustainability 2019, 11, 1073. [CrossRef]

31. Uddin, S.F.; Khan, M.N. Young Consumer's Green Purchasing Behavior: Opportunities for Green Marketing. J. Glob. Mark. 2018, 31, 1-12. [CrossRef]

32. Vazifehdoust, H.; Taleghani, M.; Esmaeilpour, F.; Nazari, K. Purchasing green to become greener: Factors influence consumers' green purchasing behavior. Manag. Sci. Lett. 2013, 3, 2489-2500. [CrossRef]

33. Lee, K. Gender differences in Hong Kong adolescent consumers' green purchasing behavior. J. Consum. Mark. 2009, 26, 87-96. [CrossRef]

34. Gan, C.; Wee, H.Y.; Ozanne, L.; Kao, T.H. Consumers' purchasing behavior towards green products in New Zealand. Innov. Mark. 2008, 4, 93-102.

35. Chan, R.Y.; Lau, L.B. Explaining green purchasing behavior: A cross-cultural study on American and Chinese consumers. J. Int. Consum. Mark. 2002, 14, 9-40. [CrossRef]

36. Smith, J.R.; Terry, D.J.; Manstead, A.S.; Louis, W.R.; Kotterman, D.; Wolfs, J. Interaction effects in the theory of planned behavior: The interplay of self-identity and past behavior. J. Appl. Soc. Psychol. 2007, 37, 2726-2750. [CrossRef]

37. Cozzio, C.; Bullini Orlandi, L.; Zardini, A. Food sustainability as a strategic value driver in the hotel industry. Sustainability 2018, 10, 3404. [CrossRef]

38. UNEP; 2003 World Lake Vision Committee; Shiga Prefectural Government; UNEP International Environmental Technology Centre; International Lake Environment Committee. World Lake Vision: A Call to Action; ILEC-UNEP: Otsu, Japan, 2003.

39. Ajzen, I. The theory of planned behavior. Organ. Behav. Hum. Decis. Process. 1991, 50, 179-211. [CrossRef]

40. Yazdanpanah, M.; Forouzani, M. Application of the Theory of Planned Behaviour to predict Iranian students' intention to purchase organic food. J. Clean. Prod. 2015, 107, 342-352. [CrossRef]

41. Zhang, Y.; Cui, F.; Wu, S.S.; Wu, W.Z. Analysis of the factors impacting on air travelers' willingness to pay for carbon offsets: Based on theory of planned behavior and norm activation model. J. Arid Land Resour. Environ. 2017, 31, 9-14.

42. Toft, J.D.; Ogston, A.S.; Heerhartz, S.M.; Cordell, J.R.; Flemer, E.E. Ecological response and physical stability of habitat enhancements along an urban armored shoreline. Ecol. Eng. 2013, 57, 97-108. [CrossRef]

43. Al-Talabani, H.; Kilic, H.; Ozturen, A.; Qasim, S. Advancing Medical Tourism in the United Arab Emirates: Toward a Sustainable Health Care System. Sustainability 2019, 11, 230. [CrossRef]

44. Wang, J.; Wang, S.; Xue, H.; Wang, Y.; Li, J. Green image and consumers' word-of-mouth intention in the green hotel industry: The moderating effect of Millennials. J. Clean. Prod. 2018, 181, 426-436. [CrossRef]

45. Ting, C.T.; Hsieh, C.M.; Chang, H.P.; Chen, H.S. Environmental Consciousness and Green Customer Behavior: The Moderating Roles of Incentive Mechanisms. Sustainability 2019, 11, 819. [CrossRef]

46. Hsu, C.; Huang, S. An extension of the theory of planned behavior model for tourists. J. Hosp. Tour. Res. 2012, 36, 390-417. [CrossRef]

47. Zheng, S.; Cheng, Y.; Ju, Y. Understanding the Intention and Behavior of Renting Houses among the Young Generation: Evidence from Jinan, China. Sustainability 2019, 11, 1507. [CrossRef]

48. Y Pérez, L.P.; Egea, P. About Intentions to Donate for Sustainable Rural Development: An Exploratory Study. Sustainability 2019, 11, 765. [CrossRef]

49. Becker-Leifhold, C.V. The role of values in collaborative fashion consumption-A critical investigation through the lenses of the theory of planned behavior. J. Clean. Prod. 2018, 199, 781-791. [CrossRef] 
50. Brown, T.J.; Ham, S.H.; Hughes, M. Picking up litter: An application of theory-based communication to influence tourist behaviour in protected areas. J. Sustain. Tour. 2010, 18, 879-900. [CrossRef]

51. Kaplan, S.; Manca, F.; Nielsen, T.A.S.; Prato, C.G. PratoIntentions to use bike-sharing for holiday cycling: An application of the theory of planned behavior. Tour. Manag. 2015, 47, 34-46. [CrossRef]

52. Wang, C.; Zhang, J.; Cao, J.; Hu, H.; Yu, P. The influence of environmental background on tourists' environmentally responsible behaviour. J. Environ. Manag. 2019, 231, 804-810. [CrossRef] [PubMed]

53. Leelapattana, W.; Hsu, S.Y.; Thongma, W.; Chen, C.; Chiang, F.M. Understanding the Impact of Environmental Education on Tourists' Future Visit Intentions to Leisure Farms in Mountain Regions. Sustainability 2019, 11, 1567. [CrossRef]

54. Hou, J.; Hou, B. Farmers' Adoption of Low-Carbon Agriculture in China: An Extended Theory of the Planned Behavior Model. Sustainability 2019, 11, 1399. [CrossRef]

55. Bauer, D.; Arnold, J.; Kremer, K. Consumption-Intention Formation in Education for Sustainable Development: An Adapted Model Based on the Theory of Planned Behavior. Sustainability 2018, 10, 3455. [CrossRef]

56. Zhang, Y.; Lee, T.J.; Xiong, Y. A conflict resolution model for sustainable heritage tourism. Int. J. Tour. Res. 2019, 21, 478-492. [CrossRef]

57. Yang, S.; Li, L.; Zhang, J. Understanding consumers' sustainable consumption intention at china's double-11 online shopping festival: An extended theory of planned behavior model. Sustainability 2018, 10, 1801. [CrossRef]

58. Ali, S.; Ullah, H.; Akbar, M.; Akhtar, W.; Zahid, H. Determinants of Consumer Intentions to Purchase Energy-Saving Household Products in Pakistan. Sustainability 2019, 11, 1462. [CrossRef]

59. Lowe, B.; Lynch, D.; Lowe, J. Reducing household water consumption: A social marketing approach. J. Mark. Manag. 2015, 31, 378-408. [CrossRef]

60. Han, H.; Hyun, S.S. What influences water conservation and towel reuse practices of hotel guests? Tour. Manag. 2018, 64, 87-97. [CrossRef]

61. Nguyen, H.T.T.; Hung, R.J.; Lee, C.H.; Nguyen, H.T.T. Determinants of Residents' E-Waste Recycling Behavioral Intention: A Case Study from Vietnam. Sustainability 2018, 11, 1-24.

62. Kumar, A.; Sah, B.; Singh, A.R.; Deng, Y.; He, X.; Kumar, P.; Bansal, R.C. A review of multi criteria decision making (MCDM) towards sustainable renewable energy development. Renew. Sustain. Energy Rev. 2017, 69, 596-609. [CrossRef]

63. Hu, H.; Zhang, J.; Wang, C.; Yu, P.; Chu, G. What influences tourists' intention to participate in the Zero Litter Initiative in mountainous tourism areas: A case study of Huangshan National Park, China. Sci. Total. Environ. 2019, 657, 1127-1137. [CrossRef]

64. Shalender, K.; Sharma, N. Using extended theory of planned behaviour (TPB) to predict adoption intention of electric vehicles in India. Environ. Dev. Sustain. 2020, 1-17. [CrossRef]

65. Fishbein, M.; Ajzen, I. Belief, Attitude, Intention, and Behavior: An Introduction to Theory and Research; Elsevier Science Publishing Co., Inc.: New York, NY, USA, 1977.

66. Sun, J.; Willson, V.L. Assessing general and specific attitudes in human learning behavior: An activity perspective and a multilevel modeling approach. Educ. Psychol. Meas. 2007, 68, 245-261. [CrossRef]

67. Tanner, C.; Kast, S.W. Promoting sustainable consumption: Determinants of green purchases by Swiss consumers. Psychol. Mark. 2003, 20, 883-902. [CrossRef]

68. Sweeney, J.C.; Webb, D.; Mazzarol, T.; Soutar, G.N. Self-determination theory and word of mouth about energy-saving behaviors: An online experiment. Psychol. Mark. 2014, 31, 698-716. [CrossRef]

69. Castanier, C.; Deroche, T.; Woodman, T. Theory of planned behaviour and road violations: The moderating influence of perceived behavioural control. Transp. Res. Part F Traffic Psychol. Behav. 2013, 18, 148-158. [CrossRef]

70. Wang, P.; Liu, Q.; Qi, Y. Factors influencing sustainable consumption behaviors: A survey of the rural residents in China. J. Clean. Prod. 2014, 63, 152-165. [CrossRef]

71. Camilla, B.; Patrick, D.P. Positive and negative antecedents of purchasing eco-friendly products: A comparison between green and non-green consumers. J. Bus. Ethics 2016, 134, 229-247.

72. Amado, A.A.; Schilling, K.E.; Jones, C.S.; Thomas, N.; Weber, L.J. Estimation of tile drainage contribution to streamflow and nutrient loads at the watershed scale based on continuously monitored data. Environ. Monit. Assess. 2017, 189, 426. [CrossRef] 
73. Zsóka, Á.; Szerényi, Z.M.; Széchy, A.; Kocsis, T. Greening due to environmental education? Environmental knowledge, attitudes, consumer behavior and everyday pro-environmental activities of Hungarian high school and university students. J. Clean. Prod. 2013, 48, 126-138. [CrossRef]

74. Taufique, K.M.R.; Siwar, C.B.; Talib, B.A.; Chamhuri, N. Measuring Consumers' Environmental Responsibility: A Synthesis of Constructs and Measurement Scale Items. Curr. World Environ. 2014, 9, 27. [CrossRef]

75. Hansla, A.; Gamble, A.; Juliusson, A.; Gärling, T. The relationships between awareness of consequences, environmental concern, and value orientations. J. Environ. Psychol. 2008, 28, 1-9. [CrossRef]

76. Hamilton, L.C.; Hartter, J.; Safford, T.G.; Stevens, F.R. Rural environmental concern: Effects of position, partisanship, and place. Rural. Sociol. 2014, 79, 257-281. [CrossRef]

77. Kollmuss, A.; Agyeman, J. Mind the gap: Why do people act environmentally and what are the barriers to pro-environmental behavior? Environ. Educ. Res. 2002, 8, 239-260. [CrossRef]

78. Felix, R.; Hinsch, C.; Rauschnabel, P.A.; Schlegelmilch, B.B. Religiousness and environmental concern: A multilevel and multi-country analysis of the role of life satisfaction and indulgence. J. Bus. Res. 2018, 91, 304-312. [CrossRef]

79. Cruz, S.M.; Manata, B. Measurement of Environmental Concern: A Review and Analysis. Front. Psychol. 2020, 11, 363. [CrossRef] [PubMed]

80. Stern, P.C.; Dietz, T.; Kalof, L. Value orientations, gender, and environmental concern. Environ. Behav. 2013, 25, 322-348. [CrossRef]

81. Dunlap, R.E.; Van Liere, K.D.; Mertig, A.G.; Jones, R.E. New trends in measuring environmental attitudes: Measuring endorsement of the new ecological paradigm: A revised NEP scale. J. Soc. Issues 2000, 56, 425-442. [CrossRef]

82. Schultz, P.W. The structure of environmental concern: Concern for self, other people, and the biosphere. J. Environ. Psychol. 2001, 21, 327-339. [CrossRef]

83. Zaei, M.; Zaei, M. European centre for research training and development UK. Eur. J. Tour. Hosp. Res. 2013, 1, 12-21.

84. Han, H. Travelers' pro-environmental behavior in a green lodging context: Converging value-belief-norm theory and the theory of planned behavior. Tour. Manag. 2015, 47, 164-177. [CrossRef]

85. Kim, E.; Ham, S.; Yang, I.S.; Choi, J.G. The role of attitude, subjective norm, and perceived behavioral controlin the formation of consumers' behavioral intentions to read menu labels in the restaurant industry. Int. J. Hosp. Manag. 2013, 35, 203-213. [CrossRef]

86. Chuang, L.M.; Chen, P.C.; Chen, Y.Y. The determinant factors of travelers' choices for pro-environment behavioral intention-integration theory of planned behavior, unified theory of acceptance, and use of technology 2 and sustainability values. Sustainability 2018, 10, 1869. [CrossRef]

87. Tunn, V.S.C.; Bocken, N.M.P.; van den Hende, E.A.; Schoormans, J.P.L. Business models for sustainable consumption in the circular economy: An expert study. J. Clean. Prod. 2019, 212, 324-333. [CrossRef]

88. Verma, V.K.; Chandra, B.; Kumar, S. Values and ascribed responsibility to predict consumers' attitude and concern towards green hotel visit intention. J. Bus. Res. 2019, 96, 206-216. [CrossRef]

89. Lin, P.C.; Huang, Y.H. The influence factors on choice behavior regarding green products based on the theory of consumption values. J. Clean. Prod. 2012, 22, 11-18. [CrossRef]

90. Zhao, H.H.; Gao, Q.; Wu, Y.P.; Wang, Y.; Zhu, X.D. What affects green consumer behavior in China? A case study from Qingdao. J. Clean. Prod. 2014, 63, 143-151. [CrossRef]

91. Yadav, R.; Pathak, G.S. Determinants of consumers' green purchase behavior in a developing nation: Applying and extending the theory of planned behavior. Ecol. Econ. 2017, 134, 114-122. [CrossRef]

92. Han, H.; Kim, Y. An investigation of green hotel customers' decision formation: Developing an extended model of the theory of planned behavior. Int. J. Hosp. Manag. 2010, 29, 659-668. [CrossRef]

93. Han, H.; Hsu, L.T.J.; Sheu, C. Application of the theory of planned behavior to green hotel choice: Testing the effect of environmental friendly activities. Tour. Manag. 2010, 31, 325-334. [CrossRef]

94. Chen, M.F.; Tung, P.J. Developing an extended theory of planned behavior model to predict consumers' intention to visit green hotels. Int. J. Hosp. Manag. 2014, 36, 221-230. [CrossRef]

95. Yadav, R.; Pathak, G.S. Young consumers' intention towards buying green products in a developing nation: Extending the theory of planned behavior. J. Clean. Prod. 2016, 135, 732-739. [CrossRef]

96. Yadav, R.; Pathak, G.S. Intention to purchase organic food among young consumers: Evidences from a developing nation. Appetite 2016, 96, 122-128. [CrossRef] 
97. Wu, S.I.; Chen, J.Y. A model of green consumption behavior constructed by the theory of planned behavior. Int. J. Mark. Stud. 2014, 6, 119-132. [CrossRef]

98. Sreen, N.; Purbey, S.; Sadarangani, P. Impact of culture, behavior and gender on green purchase intention. J. Retail. Consum. Serv. 2018, 41, 177-189. [CrossRef]

99. Thøgersen, J. Norms for environmentally responsible behaviour: An extended taxonomy. J. Environ. Psychol. 2006, 26, 247-261. [CrossRef]

100. Wu, K.S.; Man, T.Y. Applying the extended theory of planned behavior to predict the intention of visiting a green hotel. Afr. J. Bus. Manag. 2011, 5, 7579-7587.

101. IBIMA. Green awareness and its impact on consumers purchasing decision: Case of University students in the Turkish Republic of the Northern Cyprus, Milan, Italy, 25-26 April 2018. Available online: https://ibima.org/accepted-paper/green-awareness-and-its-impact-on-consumerspurchasing-decision-case-of-university-students-in-the-turkish-republic-of-the-northern-cyprus/ (accessed on 12 July 2020).

102. Bong, K.S.; Jin, B. Predictors of purchase intention toward green apparel products: A cross-cultural investigation in the USA and China. J. Fash. Mark. Manag. Int. J. 2017, 21, 70-87. [CrossRef]

103. Shukla, S. A Study on Millennial Purchase Intention of Green Products in India: Applying Extended Theory of Planned Behavior Model. J. Asia-Pac. Bus. 2019, 20, 322-350. [CrossRef]

104. Arvola, A.; Vassallo, M.; Dean, M.; Lampila, P.; Saba, A.; Lähteenmäki, L.; Shepherd, R. Predicting intentions to purchase organic food: The role of affective and moral attitudes in the Theory of Planned Behaviour. Appetite 2008, 50, 443-454. [CrossRef] [PubMed]

105. Ibrahim, A.N.H.; Borhan, M.N.; Rahmat, R.A.O. Understanding Users' Intention to Use Park-and-Ride Facilities in Malaysia: The Role of Trust as a Novel Construct in the Theory of Planned Behaviour. Sustainability 2020, 12, 2484. [CrossRef]

106. Ahmad, W.; Kim, W.G.; Anwer, Z.; Zhuang, W. Schwartz personal values, theory of planned behavior and environmental consciousness: How tourists' visiting intentions towards eco-friendly destinations are shaped? J. Bus. Res. 2020, 110, 228-236. [CrossRef]

107. Wang, S.; Fan, J.; Zhao, D.; Yang, S.; Fu, Y. Predicting consumers' intention to adopt hybrid electric vehicles: Using an extended version of the theory of planned behavior model. Transportation 2016, 43, 123-143. [CrossRef]

108. Clemente, F.; Lopes, A.; Ambrósio, V. Tourists' Perceptions on Climate Change in Lisbon Region. Atmosphere 2020, 11, 297. [CrossRef]

109. Kim, Y.; Han, H. Intention to pay conventional-hotel prices at a green hotel-a modification of the theory of planned behavior. J. Sustain. Tour. 2010, 18, 997-1014. [CrossRef]

110. Han, H.; Hsu, L.T.J.; Lee, J.S.; Sheu, C. Are lodging customers ready to go green? An examination of attitudes, demographics, and eco-friendly intentions. Int. J. Hosp. Manag. 2011, 30, 345-355. [CrossRef]

111. Mohai, P. Women and the environment: An examination of the gender gap in environmental concern and activism. Soc. Nat. Resour. 1992, 5,1-19. [CrossRef]

112. Diamantopoulos, A.; Schlegelmilch, B.B.; Sinkovics, R.R.; Bohlen, G.M. Can socio-demographics still play a role in profiling green consumers? A review of the evidence and an empirical investigation. J. Bus. Res. 2003, 56, 465-480. [CrossRef]

113. Laroche, M.; Bergeron, J.; Barbaro-Forleo, G. Targeting consumers who are willing to pay more for environmentally friendly products. J. Consum. Mark. 2001, 18, 503-520. [CrossRef]

114. Dagher, G.; Itani, O.; Kassar, A.N. The impact of environment concern and attitude on green purchasing behavior: Gender as the moderator. Contemp. Manag. Res. 2015, 11, 179-206. [CrossRef]

115. Cheng, J.C.H.; Chiang, A.H.; Yuan, Y.; Huang, M.Y. Exploring Antecedents of Green Tourism Behaviors: A Case Study in Suburban Areas of Taipei, Taiwan. Sustainability 2018, 10, 1928. [CrossRef]

116. Maichum, K.; Parichatnon, S.; Peng, K.C. Application of the extended theory of planned behavior model to investigate purchase intention of green products among Thai consumers. Sustainability 2016, 8, 1077. [CrossRef]

117. Hair, J.F.; Ringle, C.M.; Sarstedt, M. Partial least squares structural equation modeling: Rigorous applications, better results and higher acceptance. Long Range Plan. 2013, 46, 1-12. [CrossRef]

118. Bagozzi, R.P. Attitudes, intentions, and behavior: A test of some key hypotheses. J. Personal. Soc. Psychol. 1981, 41, 607. [CrossRef] 
119. Chin, W.W. Commentary: Issues and opinion on structural equation modelling. Manag. Inf. Syst. Res. Cent. Univ. Minn. 1998, 22, vii-xvi.

120. Fornell, C.; Larcker, D.F. Structural equation models with unobservable variables and measurement error: Algebra and statistics. J. Mark. Res. 1981, 18, 382-388. [CrossRef]

121. Anderson, J.C.; Gerbing, D.W. Structural equation modeling in practice: A review and recommended two-step approach. Psychol. Bull. 1988, 103, 411. [CrossRef]

122. Henseler, J.; Hubona, G.; Ray, P.A. Using PLS Path Modeling in New Technology Research: Updated Guidelines. Industrial Management \& Data Systems, 2016. Available online: https://www.emerald.com/ insight/content/doi/10.1108/IMDS-09-2015-0382/full/html (accessed on 12 July 2020).

123. Zhang, L.; Chen, L.; Wu, Z.; Zhang, S.; Song, H. Investigating young consumers' purchasing intention of green housing in China. Sustainability 2018, 10, 1044. [CrossRef]

124. Wang, X.; Pacho, F.; Liu, J.; Kajungiro, R. Factors Influencing Organic Food Purchase Intention in Developing Countries and the Moderating Role of Knowledge. Sustainability 2019, 11, 209. [CrossRef]

(C) 2020 by the authors. Licensee MDPI, Basel, Switzerland. This article is an open access article distributed under the terms and conditions of the Creative Commons Attribution (CC BY) license (http://creativecommons.org/licenses/by/4.0/). 